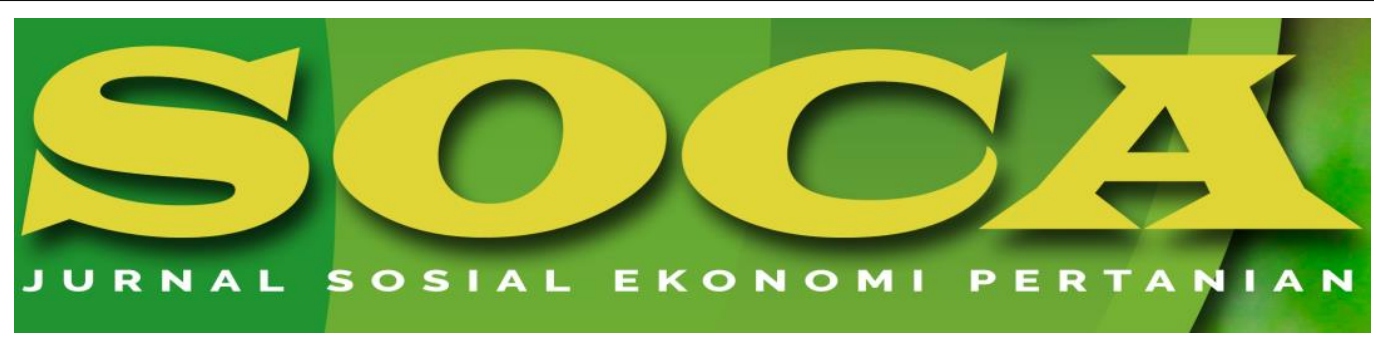

https://ojs.unud.ac.id/index.php/soca

\title{
The Feasibility of Mango Farming Agribusiness in Oro Oro Ombo Wetan Village, Pasuruan Regency
}

\author{
Sri Kusmaryatun, Agnes Quartina Pudjiastuti, Budi Prihatminingtyas \\ Tribhuwana Tunggadewi University, Malang, East Java \\ Email: s.kusmaryatun@gmail.com, agnespudjiastuti@yahoo.com, hatmining@yahoo.co.id \\ Handphone: 085649222424, 081555761529, 0818531559
}

Submitted: February 9th, 2020; Revised: February 16 th 2020 ; Accepted: April 21th 2020

\begin{tabular}{l} 
Keywords: \\
mango; \\
price; \\
production; \\
feasibility; \\
sensitivity; \\
\hline
\end{tabular}

\begin{abstract}
Oro-Oro Ombo Wetan Village in Rembang District was an area that produce the highest mango commodity in Pasuruan Regency with a productivity level of $72.95 \mathrm{~kg} /$ tree in 2017 . The high productivity level didn't correlate positively with the income. This situation affected by the mango commodity price on the farmer level, investment cost, and production infrastructure cost. The mango production and price in this village relatively fluctuated. Therefore, it important to assess the feasibility and sensitivity of the mango farming agribusiness in this village. This study aimed to know the mango farming agribusiness feasibility in Oro Oro Ombo Wetan Village, Rembang District, Pasuruan Regency, and its sensitivity to the price and production volume change. The survey technique conducted to collect the data. The agribusiness farming feasibility analyzed in the interest level of $8 \%$ with the investment criteria of: gross $B / C$, net $B / C$, break-even point, payback period, NPV and IRR. The sensitivity analysis used to know the feasibility percentage when the price decrease as much as $10 \%$ and the mango production decrease as much as 20\%. The result showed that the mango farming agribusiness in Oro-Oro Ombo Wetan village feasible to be conducted. This agribusiness was not sensitive to the decrease of the $10 \%$ price and $20 \%$ mango volume production.
\end{abstract}

How to Cite (APA $6^{\text {th }}$ Style):

Kusmaryatun, S., Pudjiastuti, A. Q., \& Prihatminingtyas, B. (2020). The Feasibility of Mango Farming Agribusiness in Oro Oro Ombo Wetan Village , Pasuruan Regency. SOCA: Jurnal Sosial Ekonomi Pertanian, 14(3), 466-475. https: / /doi.org/https:/ /doi.org/ 10.24843/SOCA.2020.v14.i03.p08 


\section{INTRODUCTION}

The Indonesia national government implemented constant efforts to improve the non-oil and gas export volume, such as horticultural commodity to increase the foreign exchange. To elaborate this aim in the real field, some activities such as agriculture practices (gap) for fruit and vegetables, good handling practices, good manufacturing practices and standard operating procedures (SOP) required to produce the internationally standardized product. Unfortunately, these activities could not improve the competitiveness of the mango product in the international market.

Mango farming agribusiness was not only potentially improve the export market proportion, but the domestic market also required specific consideration due to the invasion of the imported mango to the modern market (supermarket and mini market), fruit-shop dan hotel. Pudjiastuti et al. (2013); Pudjiastuti (2014) and Pudjiastuti and Kembauw (2018) highlighted that the agricultural import did not only majorly impact the balance of the trade, but also other sectors. Malay, India, Pakistan, and the Philippine also viewed Indonesia as a potential market segment because of the high population density and low local mango commodity production. The Minister of Industry and Trade through the local stakeholder needed to perform efforts in improving the mango productivity to improve the farmer income that finally also contributed to the foreign exchange.

Oro-Oro Ombo Wetan Village, Rembang District was an area that produce the highest mango commodity in Pasuruan Regency. The Gadung Klonal 21 was the variety of mango that highly popular in Rembang District. This area also set as a mango picking tourism in Pasuruan Regency (National Institute of Statistical Data, 2018). From a total of 4.000 hectares of mango land that spread in Rembang, Sukorejo, Wonorejo, Nguling, and Grati District, Gadung Klonal 21 mango variety majorly contributes to the mango total productivity in Pasuruan Regency with the total of $72.95 \mathrm{~kg} /$ tree in the year of 2017. The productivity of the Gadung Kulon 21 variety of mango expected to contribute to the farmer income.

Generally, the high productivity was the indicator used to assess the mango commodity agribusiness. The high productivity did not positively correlate with the farmer income. This affected by the mango price on the farmer level, investment cost, and production infrastructure cost. The mango commodity productivity also fluctuated due to climate change, which couldn't be store in a long period and high supply in the harvested period but the demand remained constant. One year ago, the mango price and production fluctuated with a total of $10 \%$ and $20 \%$, respectively.

The previous study completed by Supriatna (2007), Akwandi et al. (2016), Saleh et al. (2019), Pasaribu et al. (2016), Gusmawati et al. (2014), Buharman (2015), Purnama et al. (2014) and Widowati et al. (2018) showed that the annual plant agribusiness farming (orange, cacao, cloves, coffee, tea) feasible to be conducted. (Suhaeni et al., 2015) and (Muhlis et al., 2017) also stated that the mango farming agribusiness feasible to be conducted with the value of $\mathrm{R} / \mathrm{C}>1$. There was no study about the mango farming agribusiness feasibility reviewed by other criteria. The most important question is: "how was the prospect of mango commodity?"

This study aimed to know the mango farming agribusiness feasibility in Oro Oro Ombo Wetan Village, Rembang District, Pasuruan Regency and its sensitivity on the $10 \%$ price and $20 \%$ production decrease. 


\section{RESEARCH METHODS}

This study conducted in Oro-Oro Ombo Wetan Village, Rembang District, Pasuruan Regency, East Java Province. This study location chosen due to some reasons: this village was the mango central production area and set as mango area on the horticultural action plan in Pasuruan Regency by the local stakeholder.

There were 30 mango farmers in Oro-Oro Ombo Wetan Village. Therefore all farmers involved as the participant. This method defined as a census sampling technique (Ghozali, 2012).

This study employed primary and secondary data. The primary data collected from the interview, observation, and questionnaire method in September to November 2019. The secondary data collected by documentation and literature review technique.

The data collected to examine the mango agribusiness feasibility were edited, tabulated, and analyzed using the investment criteria: Gross Benefit-Cost Ratio (Gross B/C), Net Benefit-Cost Ratio (Net B/C), Payback Period (PP), Break-Even Point (BEP), Net Present Value (NPV) dan Internal Rate of Return (IRR). The NPV and IRR value calculated based on the $8 \%$ of the current interest level. The amount of the interest level set based on the assumption that the mango farming agribusiness was categorized as small-scale business that follows the level of interest determined by Rakyat Indonesia Bank or Mandiri Bank policies about the interest level of the small-scale business. The feasibility analysis was done according to the assumption that the all farmer was cultivating mango in the same period. Therefore all the mango trees were having the same age when the study conducted. Some mango seeds were provided by the government, but we calculated the seed cost as the initial cost in this study. The time analysis ranged determined in 10 years due to the highest productivity at this age (some mango tree also could stay productive until at the age of 15 years old). The mango volume production assumed to be constant until it reaches 10 years of age. The depreciation on the devices used comprehensively calculated as the cost during its economical age.

The Gross B/C was the ratio between the investment revenue (gross benefit) with the gross cost. If the gross $\mathrm{B} / \mathrm{C}$ value $>1$, the agribusiness stated as feasible, b) if the gross $\mathrm{B} / \mathrm{C}$ value $<1$, the agribusiness stated as not feasible, and $\mathrm{c}$ ) if the gross $\mathrm{B} / \mathrm{C}$ value $=1$, the agribusiness stated in a neutral state.

The net $\mathrm{B} / \mathrm{C}$ was the ratio between the positive net benefit (already cut by discount) with negative net benefit (already cut by discount). If the net $\mathrm{B} / \mathrm{C}>0$, the agribusiness stated as feasible.

The break-even point analysis correlated with the fixed cost and variable cost. BEP was a condition where the company didn't obtain profit and loss. Producer should produce higher production volumes in the BEP state to obtain more profit (Anindita et al., 2011).

The PP was the duration of a project investment evaluation based on the repayment of the investment cost for the net benefit. If the PP shorter than the business economic age, the business stated in a feasible state and vice versa.

The NPV was the difference between the present value benefit (revenue) with the present value costs (cost). To determine the value of NPV, the discount rate must be set first (Kadariah, 2001). If the value of NPV $>0$ on the current interest level, the business was feasible to conduct, if the value of NPV $<0$ on the current interest level, the business 
stated as not feasible to be conducted, and if the value of NPV $=0$, the business was in the neutral position.

IRR was a discount rate that produced the present value with the same amount of benefits with the amount the investment project (Kadariah, 2001). If the IRR value > current interest level, the business was feasible to conduct, if the IRR value < current interest level, the business was not feasible to conduct, and if the value IRR = current interest level was in a neutral position.

Sensitivity analysis conducted to know the mango farming agribusiness response on the price and volume production change. The change happened was the $10 \%$ decrease in the mango price and $20 \%$ of the mango volume production. The sensitivity analyzed done to calculate the possibilities of those changes.

\section{RESULTS AND DISCUSSION}

\section{Oro-Oro Ombo Village Farmer's Characteristic}

The characteristic of mango farmer was consisted of age, educational level background, the number of family member, and the size of the cultivating land. The distribution of the characteristic is shown by the pie chart in Figure 1.

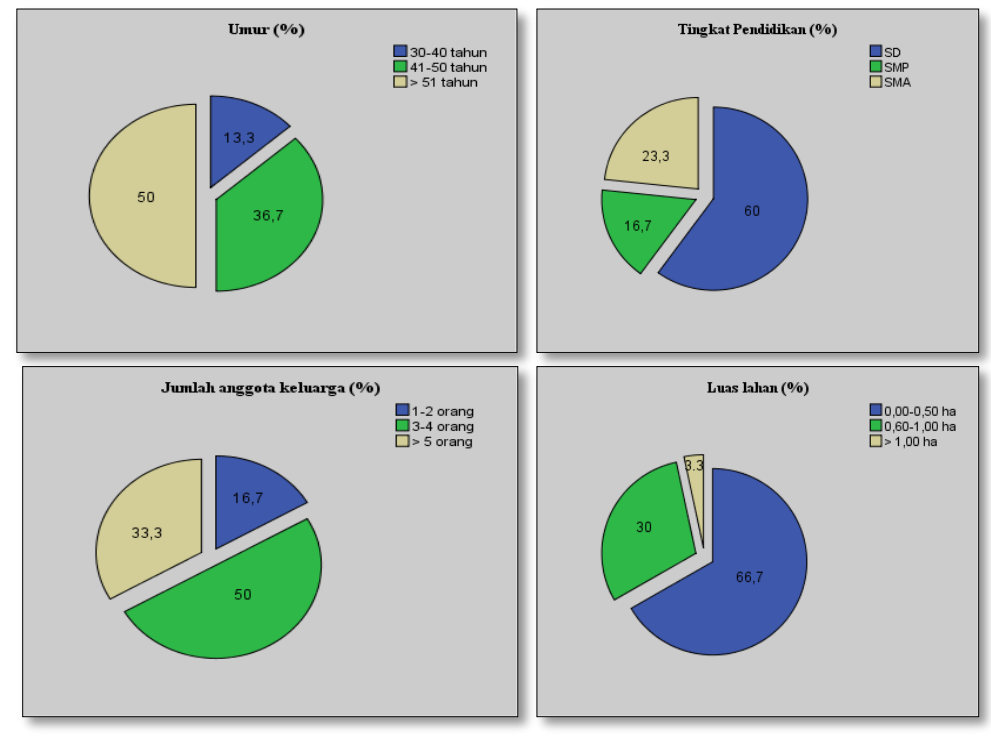

Figure 1. The Mango Farmer Distribution Based on the Characteristic Source: Primary Data (Processed), 2019

Information :

Age $(\%)$

30-40 years old

41-50 years old

$>50$ years old

The number of family member (\%)

1-2 member

3-4 member

$>5$ member

Educational Level Background (\%)

Elementary School

Junior High School 
Senior High School

The size of the cultivating land

$0.00-0.50$ ha

$0.60-1.00$ ha

$>1.00$ ha

Generally, the participant were in productive age (30 - 57 years of age). There were no farmers that graduated from the university. Most farmers $(60 \%)$ only graduated from elementary school.

The worker in the agricultural field usually didn't need a high level of educational background. Worker in a productive range of age also preferred. The knowledge of mango agribusiness obtained by learning from the non-formal educational institution (extension), mass media, electronic media, and the other source of information. Most farmers $(66.7 \%)$ were having $1-4$ family members. Almost all farmers $(96.7 \%)$ had the size of cultivated land that less than 1 ha. This was encouraging the farmer to cultivate their mango commodity in the best manner to meet their family need.

\section{Investment Cost}

The investment cost consisted of the land rent, seed, and agricultural devices cost. The investment cost used in the mango farming agribusiness was IDR $10,408,967$ that consisted of land rent, seed, and agricultural devices cost. The total of land rent, seed, and agricultural cost was IDR 995,000, IDR 1,131,667, and IDR $8,282,300$, respectively.

\section{Operational Cost}

The fixed cost consisted of the land rent, seed, and depreciation of the agricultural cost in ten years period. According to the result, the total of fixed costs in ten years IDR $24,261,556 /$ ha. The fixed cost in the first year and the second to the tenth year respectively was IDR 3,444,656/ha and IDR 2,312,989/ha. The variable cost consisted of fertilizer cost (NPK, ZA, and SP36), medication cost (insecticide, fungicide, and herbicide) and worker salary (land tillage, cultivation, maintain, harvest, and post-harvest). According to the analysis, the variable cost in the mango farming agribusiness in ten years was IDR $112,907,500 /$ ha. The first year, the second to the fourth year, the fifth to the tenth year cost variable was IDR $12,179,000 / \mathrm{ha}$, IDR 6,576,500/ha, and IDR 13,499,833/ha.

\section{Production and Revenue}

The mango volume production calculated according to the number of mango commodities distributed to the market. The farmer usually sold the mango commodity to the wholesaler with the selling price of IDR 25,000/kg. Mango plant would be actively producing its fruit at the fifth cultivating year with the total production of $4,855 \mathrm{~kg} / \mathrm{ha}$ and selling price of IDR $25,000 / \mathrm{kg}$, therefore the gross income obtained was IDR $121.372 .333 /$ ha. The mango volume production relatively constant throughout the year (except if attacked by pest or uncertain climate change). The total volume production was $29,120 \mathrm{~kg} / \mathrm{ha}$, or IDR $782,240,000 /$ ha in ten years. 


\section{Mango Farming Agribusiness Feasibility}

The feasibility study conducted based on the investment criteria: Gross B/C, Net B/C, PP, BEP, NPV, and IRR that shown in Table 1. NPV and IRR calculated based on the $8 \%$ level of interest.

The value of gross $\mathrm{B} / \mathrm{C}$ on the mango farming agribusiness was 4.62. This result indicated the IDR 1.00 would obtain the revenue of IDR 4.62. This calculation showed that this business was feasible due to the value of the gross $\mathrm{B} / \mathrm{C}>1$.

The value of net $\mathrm{B} / \mathrm{C}$ on the mango farming agribusiness This calculation showed that this business was feasible due to the value of the net $\mathrm{B} / \mathrm{C}>1$.

The value of the PP was 5.2 years. This result indicated that the investment cost would return after 5.2 years. The value of PP shorter than the business economical age, therefore this agribusiness was feasible to be conducted.

Table 1. The Calculation of Gross B/C, Net B/C, Payback Period, BEP, NPV and IRR

\begin{tabular}{lccccccc}
\hline Year & Benefit & Cost Total & Net Benefit & df 8\% & NPV 8\% & df 80\% & NPV 80\% \\
\hline 1 & - & $15,623,656$ & $-15,623,656$ & 0.925926 & $-14,466,348$ & 0.555556 & $-8,679,809$ \\
2 & - & $8,889,489$ & $-8,889,489$ & 0.857339 & $-7,621,304$ & 0.308642 & $-2,743,669$ \\
3 & - & $8,889,489$ & $-8,889,489$ & 0.793832 & $-7,056,763$ & 0.171468 & $-1,524,261$ \\
4 & - & $8,889,489$ & $-8,889,489$ & 0.73503 & $-6,534,040$ & 0.09526 & $-846,812$ \\
5 & $105,560,511$ & $15,812,822$ & $89,747,689$ & 0.680583 & $61,080,769$ & 0.052922 & $4,749,641$ \\
6 & $105,560,511$ & $15,812,822$ & $89,747,689$ & 0.63017 & $56,556,268$ & 0.029401 & $2,638,689$ \\
7 & $105,560,511$ & $15,812,822$ & $89,747,689$ & 0.58349 & $52,366,914$ & 0.016334 & $1,465,938$ \\
8 & $105,560,511$ & $15,812,822$ & $89,747,689$ & 0.540269 & $48,487,884$ & 0.009074 & 814,410 \\
9 & $105,560,511$ & $15,812,822$ & $89,747,689$ & 0.500249 & $44,896,189$ & 0.005041 & 452,450 \\
10 & $105,560,511$ & $15,812,822$ & $89,747,689$ & 0.463193 & $41,570,545$ & 0.002801 & 251,361 \\
\hline$\sum$ & $633,363,067$ & $137,169,056$ & $496,194,011$ & & $269,280,114$ & & $-3,422,061$ \\
\hline
\end{tabular}

Source: Primary Data (Processed), 2019.

The BEP production was IDR 2,844 and the BEP price was $7,322 / \mathrm{kg}$. This result showed that the BEP production and BEP price was higher than the production volume and mango selling price. Therefore this business was profitable and feasible to be developed.

The NPV flow (already cut by discount) on the $8 \%$ level of interest was IDR $269,280,114$. This result showed that the NPV value was positive and financially this business was feasible to conduct.

The IRR value was $79 \%$. This indicated that business was feasible due to the value of IRR higher than the level of interest (8\%).

\section{Sensitivity Analysis on the Decrease of $\mathbf{1 0 \%}$ of Mango Price}

The mango commodity price in Oro-Oro Ombo Wetan Village on the farmer level was IDR $12,500 / \mathrm{kg}$. The price fluctuation that often happened was the $10 \%$ price decrease (to IDR $11,250 / \mathrm{kg}$ ). Sensitivity analysis of the mango farming agribusiness is shown in Table 2 . 
The $10 \%$ price decrease produces the value of grass B/C of 2.39. The IDR 1.00 produce the revenue of IDR 2.39. This calculation showed that mango farming agribusiness was feasible due to the value of Gross B $/ C>1$.

The $10 \%$ price decrease produced the value of the Net B/C of 1.39 . The IDR 1.00 produced the net income of IDR 1.39. This calculation showed that the mango agribusiness commodity was feasible to be developed due to the value of $\mathrm{Net} B / \mathrm{C}>$ 0 .

Table 2. Investment Criteria with the Decrease of 10\% Mango Price

\begin{tabular}{lccccccc}
\hline Year & Benefit & Cost Total & Net Benefit & df 8\% & NPV 8\% & df 80\% & NPV 80\% \\
\hline 1 & - & $15,623,656$ & $-15,623,656$ & 0.925926 & $-14,466,348$ & 0.555556 & $-8,679,809$ \\
2 & - & $8,889,489$ & $-8,889,489$ & 0.857339 & $-7,621,304$ & 0.308642 & $-2,743,669$ \\
3 & - & $8,889,489$ & $-8,889,489$ & 0.793832 & $-7,056,763$ & 0.171468 & $-1,524,261$ \\
4 & - & $8,889,489$ & $-8,889,489$ & 0.73503 & $-6,534,040$ & 0.09526 & $-846,812$ \\
5 & $54,618,000$ & $15,812,822$ & $38,805,178$ & 0.680583 & $26,410,152$ & 0.052922 & $2,053,653$ \\
6 & $54,618,000$ & $15,812,822$ & $38,805,178$ & 0.63017 & $24,453,844$ & 0.029401 & $1,140,919$ \\
7 & $54,618,000$ & $15,812,822$ & $38,805,178$ & 0.58349 & $22,642,449$ & 0.016334 & 633,844 \\
8 & $54,618,000$ & $15,812,822$ & $38,805,178$ & 0.540269 & $20,965,230$ & 0.009074 & 352,135 \\
9 & $54,618,000$ & $15,812,822$ & $38,805,178$ & 0.500249 & $19,412,250$ & 0.005041 & 195,631 \\
10 & $54,618,000$ & $15,812,822$ & $38,805,178$ & 0.463193 & $17,974,306$ & 0.002801 & 108,684 \\
\hline Total & $327,708,000$ & $137,169,056$ & $190,538,944$ & & $96,179,776$ & & $-9,309,685$ \\
\hline
\end{tabular}

Source: Primary Data (Processed), 2019.

The investment PP of the mango agribusiness with the decrease of the $10 \%$ price was 6.3 years. This result indicated that the return of investment happened after 6.3 years. The value of PP was lower than the economical age of a business, therefore the agribusiness was feasible to be conducted in the study location.

The BEP production was 3,212 $\mathrm{kg}$ and the BEP price was IDR $8,416 / \mathrm{kg}$. This result indicated that the BEP production and BEP price was lower than the production and mango selling price, hence it concluded that the agribusiness still profitable and feasible to be conducted if the price decrease to the $10 \%$.

NPV in mango farming agribusiness with a price decrease of $10 \%$ was IDR $96,179,776$. The NPV value was positive and financially this business was feasible to conduct.

IRR was calculated based on the $10 \%$ mango production was $73 \%$. This result indicated that mango farming agribusiness was feasible to conduct due to higher IRR value higher than the level of interest used (8\%).

\section{Sensitivity Analysis on the Decrease of $\mathbf{2 0 \%}$ of Mango Commodity Production}

The total of mango commodity production in Oro-Oro Ombo Wetan Village was $4,855 \mathrm{~kg} / \mathrm{ha}$. If the commodity production decrease as much as $20 \%$ or $3,884 \mathrm{~kg} / \mathrm{ha}$, the investment criteria calculated show in Table 3.

This result indicated that the IDR 1.00 in the production cost produced the revenue as much as IDR 2.12. This calculation showed that the mango farming agribusiness due to the value of gross $\mathrm{B} / \mathrm{C}>1$.

The value of net B/C with the decrease of $20 \%$ mango volume production was 1.12. This result indicated that the IDR 1.00 in the production cost produced the 
revenue as much as IDR 1.12. This calculation showed that the mango farming agribusiness due to the value of net $\mathrm{B} / \mathrm{C}>0$.

Table 3.Investment Criteria Calculation with the Investment Criteria with 20\% Decrease of 20\% Produksi Mangga

\begin{tabular}{cccccccc}
\hline Year & Benefit & Total Cost & Net Benefit & df 8\% & NPV 8\% & df 50\% & NPV 50 \% \\
\hline 1 & - & $15,623,656$ & $-15,623,656$ & 0.925926 & $-14,466,348$ & 0.666667 & $-10,415,770$ \\
2 & - & $8,889,489$ & $-8,889,489$ & 0.857339 & $-7,621,304$ & 0.444444 & $-3,950,884$ \\
3 & - & $8,889,489$ & $-8,889,489$ & 0.793832 & $-7,056,763$ & 0.296296 & $-2,633,923$ \\
4 & - & $8,889,489$ & $-8,889,489$ & 0.73503 & $-6,534,040$ & 0.197531 & $-1,755,948$ \\
5 & $48,549,333$ & $15,812,822$ & $32,736,511$ & 0.680583 & $22,279,919$ & 0.131687 & $4,310,981$ \\
6 & $48,549,333$ & $15,812,822$ & $32,736,511$ & 0.63017 & $20,629,555$ & 0.087791 & $2,873,987$ \\
7 & $48,549,333$ & $15,812,822$ & $32,736,511$ & 0.58349 & $19,101,440$ & 0.058528 & $1,915,992$ \\
8 & $48,549,333$ & $15,812,822$ & $32,736,511$ & 0.540269 & $17,686,518$ & 0.039018 & $1,277,328$ \\
9 & $48,549,333$ & $15,812,822$ & $32,736,511$ & 0.500249 & $16,376,406$ & 0.026012 & 851,552 \\
10 & $48,549,333$ & $15,812,822$ & $32,736,511$ & 0.463193 & $15,163,339$ & 0.017342 & 567,701 \\
\hline Total & $291,296,000$ & $134,664,622$ & $137,169,056$ & & $75,558,723$ & & $-6,958,985$ \\
\hline
\end{tabular}

Source: Primary Data (Processed), 2019.

The investment PP of the mango agribusiness with the decrease of the $20 \%$ production volume was 6.7 years. This result indicated that the return of investment happened after 6.7 years. The value of PP was lower than the economical age of a business, therefore the agribusiness was feasible to be conducted in the study location.

The BEP production was $3,516 \mathrm{~kg}$ and the BEP price was IDR $8,821 / \mathrm{kg}$. This result indicated that the BEP production and BEP price was lower than the production and mango selling price, hence it concluded that the agribusiness still profitable and feasible to be conduct.

The NPV flow (already cut by discount) on the $8 \%$ level of interest was IDR $75,558.723$. This result showed that the NPV value was positive and financially this business was feasible to conduct.

IRR value with the decrease of the $20 \%$ mango production was $73 \%$. This result indicated that mango farming agribusiness was feasible to conduct due to higher IRR value higher than the level of interest used $(8 \%)$.

The result from mango farming agribusiness feasibility and sensitivity contributed as a reference in cultivating the mango due to the high capital return (more than 10 times) in comparison with the bank interest level. If the mango commodity price decrease as much as $10 \%$ or the production volume decrease as much as $20 \%$, this agribusiness still had high capital return (reached 9 times of the bank interest level). The local stakeholder majorly contributed to this agribusiness by the establishment of the mango-picking tourism. The promotion of a way to consume the mango variety of clonal 21 was also increasing the demand for mango in the various market segment with a price higher than the BEP standard. The farmer in the study location also obtain more benefit due to the well-maintained soil condition. The soil quality in this village was better than the other area in Pasuruan Regency. Therefore, the farmer in this village could produce more mango commodities and no significant effect happened due to the $20 \%$ decrease in the production. 


\section{CONCLUSION}

The mango agribusiness in Oro-Oro Ombo Wetan Village was feasible to be developed. This conclusion made based on the result on the investment criteria with the value of gross B/C, Net B/C, payback period, BEP volume production, BEP price, and IRR was 4.62, 3.62, 5.2 years, 2,844 kg, IDR 7,322, IDR 269,280,114 and 79\%. The mango farming agribusiness in Oro-Oro Ombo Wetan Village was not sensitive to the $10 \%$ price decrease with the value of Gross B/C 2.38; Net B/C 1.38; payback period 6.7 years; BEP production 3,212 kg; BEP price IDR 8,416; NPV IDR $96,179,776$; and IRR $73 \%$. The value of the investment criteria on the $20 \%$ volume decrease was gross B/C 2.12; net B/C 1.12; payback period 6.7 years; BEP production $3.516 \mathrm{~kg}$; BEP price IDR 8,821; NPV IDR 75,558,723; and IRR 73\%.

\section{RECOMMENDATION}

This study showed that the mango farming was insensitive on price and production volume change. Results showed that there was no effect of the $10 \%$ price decrease and $20 \%$ production volume change on agribusiness feasibility. But the effort of maintaining the uniqueness of the mango produce and the way to consume it is really important, especially on the variety of mango-avocado. This was important due to maintain the bargaining position especially in determining the selling price.

Further study required to examine the comparation of the mango farming agribusiness in different area and variety. This was important in determining the position of the mango farming agribusiness in Oro-Oro Ombo Wetan Village among wider area East Java, Java Island, and national level.

\section{REFERENCES}

Akwandi, L., Dumasari., \& Pujiharto. (2016). Analisis Kelayakan Usahatani Tanaman Jeruk di Desa Karangcengis, Kecamatan Bukateja, Kabupaten Purbalingga. Agritech, XVIII(2), 87-92.

Anindita, R., Heryanto, Pudjiastuti, A. Q., \& Rozi, F. (2011). Ekonomi Pertanian (1st ed.). Universitas Terbuka.

BPS. (2018). Kabupaten Pasuruan Dalam Angka. Badan Pusat Statistik.

Buharman, B. (2015). Analisis Usahatani Kakao Rakyat Di Kabupaten Solok Sumatera Barat. Jurnal Pengkajian Dan Pengembangan Teknologi Pertanian, 18(1), 81-93.

Ghozali, I. (2012). Aplikasi Analisis Multivariate dengan Program IBM SPSS. Universitas Diponegoro.

Gusmawati, Alimudin, \& Howara, L. (2014). Analisis Kelayakan Finansial Usahatani Cengkeh di Desa Boukecamatan Sojol Kabupaten Donggala Provinsi Sulawesi Tengah. E-J. Agrotekbis, 2(3), 325-331.

Kadariah. (2001). Evaluasi Proyek: Analisis Ekonomi. Lembaga Penerbitan Fakultas Ekonomi Universitas Indonesia.

Muhlis, A., Soejono, D., \& Subekti, S. (2017). Analisis Pendapatan Usahatani Mangga Gadung Di Desa Bayeman Kecamatan Arjasa Kabupaten Situbondo. Jurnal Agribest, 01(02), 7250-7257. https://doi.org/10.1128/AAC.03728-14 
Pasaribu, M. C., Prasmatiwi, F. E., \& Murniati, K. (2016). Analisis Kelayakan Finansial Usahatani Kakao Di Kecamatan Bulok Kabupaten Tanggamus. JIIA, 4(4), 367-375. http://sinta2.ristekdikti.go.id

Pudjiastuti, A. Q. (2014). Perubahan Neraca Perdagangan Indonesia Sebagai Akibat Penghapusan Tarif Impor Gula. Agriekonomika, 3(2), 106-116.

Pudjiastuti, A. Q., Anindita, R., Hanani, N., \& Kaluge, D. (2013). Effects of Sugar Price Increase in Indonesia. Oeconomica, 58(1), 28-39. https: / / doi.org/http:/ / studiaoeconomica.ubbcluj.ro/volumes.html

Pudjiastuti, A. Q., \& Kembauw, E. (2018). Sugar Price Policy and Indonesia's Trade Balance. Journal of Advanced Research in Law and Economics, 8(8). https://doi.org/10.14505/jarle.v8.8(30).26

Purnama, I. N., Sarma, M., \& Najib, M. (2014). Strategi Peningkatan Pemasaran Mangga di Pasar Internasional. Jurnal Holtikultura, 24(1), 85-93.

Saleh, M., Hasan, I., \& Nurliani. (2019). Analisis Kelayakan Usahatani Kakao ( Theobroma cacao L .) Perkebunan Rakyat. Wiratani, 2(2), 106-116.

Suhaeni, S., Karno, K., \& Sumekar, W. (2015). Value Chain Agribisnis Mangga Gedong Gincu (Mangifera Indica 1) di Kabupaten Majalengka. AGRARIS: Journal of Agribusiness and Rural Development Research, 1(2), 125-135. https://doi.org/10.18196/agr.1216

Supriatna, A. (2007). Kajian Kelayakan Usahatani Dan Marjin Tataniaga Mangga (Mangifera indica) (Studi kasus di Kabupaten Majalengka, Jawa Barat). Jurnal Pengkajian Dan Pengembangan Teknologi Pertanian, 10(2), 166-178.

Widowati, Pudjiastuti, A. Q., \& Sa'diyah, A. A. (2018). Kelayakan Usaha Tanaman Jati. Agribisnis Dan Pengembangan Ekonomi Perdesaan V, 153-159. 